\title{
Online Promotion as a Coping Strategy for Career Plateau
}

\author{
A.R.Shakila Devia, S.Rabiyathul Basariyab
}

\begin{abstract}
PROMOTION could be a vertical growth of Associate in Nursing worker among the organization. in alternative words, promotion is outlined because the upward movement of Associate in Nursing worker from one job to a different higher one, with increase in remuneration, standing and responsibilities.

Promotion is also temporary or permanent, relying upon the requirements of the organization. there are often dry promotion additionally wherever Associate in Nursing worker is assigned to a higher-level job while not increase in pay. There are several cope methods for plateaued staff. the foremost effective and predominant strategy is promotion.
\end{abstract}

Key words: Promotion, Transfer, Career plateau, plateau coping strategy

\section{INTRODUCTION}

Promotion reflects the career growth of an employee. It is a powerful tool for every organisation to retain the talented employees who are the assets to an organisation. According to Scott and haberdasher, a promotion is that the transfer of associate degree worker to employment that pays extra money or one that carries some most popular standing. Promotion has associate degree in-built psychological feature price because it elevates the authority, power and standing of associate degree worker among a corporation.

\section{OBJECTIVE}

- To define the purpose, types and policy for employee promotion.

- To define the types and need for employee transfers.

- Observation of case studies where strategies for coping of career plateau are followed.

- To draw relation between promotion and career plateau

\section{PURPOSE OF PROMOTION}

Promotion is a way of adding responsibilities to an employee that helps to boost the employee motivation. This will help to increase the productivity of the employee. Also helps the

Revised Manuscript Received on September 22, 2019

A.R.ShakilaDevia, Research Scholar, Bharath Institute of Higher Education and Research, Chennai, shakilasuraj@yahoo.com.

Dr.S.Rabiyathul Basariyab, Associate Professor \& Research Supervisor, Dept of Commerce \& Business Administration, Bharath Institute of Higher Education and Research, Chennai, srabiyathulbasariya@gmail.com. organisation to retain the valuable employees. The following are the purposes or objectives of promotion:

- To acknowledge AN employee's talent and information and utilize it to enhance the structure effectiveness.

- To reward and encourage staff to higher productivity.

- To develop competitive spirit and embody the zeal within the staff to amass talent, information etc.,

- To push employee's satisfaction and boost their morale

- To make loyalty among the staff towards organization.

- To push smart human relations.

- To extend sense of belongingness.

- To retain sure-handed and gifted folks.

- To draw in trained, competent and industrious folks.

- To impress the opposite staff that opportunities are accessible

- To them too if they conjointly perform well.

\subsection{Types of promotion}

Horizontal promotion: when an employees is shifted in the same category, it is called as horizontal promotion. A junior clerk promoted to senior clerk is such an example.

Vertical promotion: this is the kind of promotion when an employee is promoted from a lower category to higher category involving increase in salary, status, authority and responsibility. Generally, promotion, means 'vertical promotion '.

Dry promotion: when promotion is made without increase in salary, it is called 'dry promotion '. For example, a lower level manager is promoted to senior level manager without increase in salary or pay. Such promotion is made either there is resource / fund crunch in the organization or some employee hanker more for status or authority than money.

\section{B. Promotion policy}

Any organisation will have different levels of jobs where the employees are selected to any particular position based on their qualification, knowledge and skills. Every organisation will have their own promotion policy. This policy will have the specification of the required qualification and experience and skill levels of the employee for each position. Seniority and loyalty to the company will also play role in the promotion policy. 
The characteristics of fine promotion policy are as follows:

- It should give equal opportunities for promotion across the work, departments and regions.

- It should be applied uniformly to all or any workers no matter their background.

- It should be truthful and impartial. the premise of promotion should be clearly nominative and

- created well-known to the workers.

- It should be related to with career designing.

- It should even be noted that promotion will be created on numerous baseed

\section{Following are the vital ones:}

- Seniority i.e. length of service

- Merit i.e. performance

- academic and technical qualification

- Potential for higher performance

- Career and succession set up

- Vacancies supported structure chart

- psychological feature methods like job enlargement

- Training

\section{TRANSFER}

A transfer refers to lateral movement of workers among constant grade, from one job to a different. in keeping with flippo, a transfer may be a amendment within the job of associate worker while not a change in responsibilities or remuneration.

Transfer differs from promotion within the sense that the latter involves a amendment of job involving increase in pay, authority, standing and responsibility, whereas of these stay unchanged / stagnant within the case of former. Also, transfers are frequent and regular whereas promotions are infrequent, if not irregular.

\section{Need for transfer}

To satisfy union needs: a corporation might designate jobs among workers so as to address changes in technology, volume of production, production schedule, line of products quality of products, structure structure, etc.,

To satisfy worker needs: workers might request for transfer so as to satisfy their need to figure in a very specific department, place and below some superior. Personal issues of worker like health, family circumstances, inhume personal conflicts might also necessitate transfer.

To higher utilize worker: once associate employee isn't acting satisfactorily on one job and management thinks that his / her capabilities would be used better elsewhere, he / she is also transferred to different jobs.

To create worker a lot of versatile: in some organizations like banks, workers once engaged on employment for nominative amount are transferred to different job with a read to widen their information and skills and additionally cut back monotony. This additionally known as job rotation.

To regulate the workforce: work force will be transferred from the departments / plants wherever there's less work to departments / plants where is a lot of work

To supply relief: transfer is also created to grant relief to the workers world health organization are burdened or doing risky work for long amount.

To penalize employee: management might use transfer as associate instrument to action, worker is transferred to remote and much - flung areas.

\section{Transfer policy}

It is vital that each organization ought to have its transfer policy. a decent transfer policy ought to satisfy the subsequent requirements:

\section{The circumstances below that transfer are created ought}

to

- be clearly nominative.

- the premise of transfer are nominative.

- The authority World Health Organization can initiate transfer are created public.

- the actual fact of transfer ought to be intimated to the person

- involved well before.

- the character of transfer, whether or not or temporary, ought

- to be processed.

- Transfer shouldn't be frequent affair and not for the sake of it solely.

\section{Types of transfer}

\section{Employee transfers are also classified as follows:}

Production transfer: this kind of transfer is created once labour demand in one division or branch is declining. the excess workers from such division are transferred to those divisions or branches wherever there's shortage of employees. Such transfer helps avoid lay off and stabilize employment.

Remedial transfer: such transfers are affected to correct the incorrect choice and placement of workers. A incorrectly placed worker is transferred to a lot of appropriate job. Such transfers shield the interest of the worker.

Replacement transfer: this transfer is affected once labour needs are declined associated are designed to switch a 
replacement worker by an employee World Health Organization has been within the organization for a sufficiently very long time. the aim of those transfer is to retain long service workers within the organization and additionally provide them some relief from the serious pressure of labor. skillfulness transfer: these transfers also are referred to as job rotation. In such transfer, workers are created to maneuver from one job to a different to realize varied and broader expertise of labor.

Shift transfer: this transfer is common wherever work progresses for twenty-four hours or in shifts. workers are transferred from one shift to a different sometimes on the premise of sympathy and convenience.

Penal transfer: management might use transfer as associate instrument to penalise workers concerned in undesirable activities within the organization.

\section{LIVING REVOLUTIONIST WITH CREATIVE THINKING}

S.Easwaramoorthy was born in sathangulam in 1937, after completing his schooling at his native place he had moved to Chennai to do his engineering at St.Xavier Engineering college. His father had an oil mill in which frequent inspections were done by Government officials. On seeing these officers his father motivated him to become as inspector of factories. After completing his engineering, he worked as a professor job and worked there for some time and continuously checking for the opening for the post of Inspector of Factories. Through employment exchange he came to know that there was a vacancy for inspector of factories and applied for the same and got selected. He has started his professional life as inspector of factories thus fulfilling his father's desires and dreams.

Gradually through his hard work and sincerity he climbed career ladder and became superintendent in the year 1978 later deputed as general manager of TPTC in Villupuram. There was a possibility for him to become as a Managing Director. but he was not satisfied with that job. even though he got a very high position he was not satisfied with the current job. Here job satisfaction dominates than a high position. Because of these reasons he moved back to the same organisation where he worked before. After few years he was promoted as deputy chief inspector. At this position he was plateaued because there was no chance of upper mobility.

Due to the organisational structure there was only one higher level position named joint chief inspector. Hence, he was stagnated at this position. To overcome this stagnation, with his intelligence he wrote a letter to State Minister
Aranganayakam in Tamilnadu Government to create a new position/designation known as additional chief inspector of factories which was equivalent to joint chief inspector and also he requested them to split into different departments such as productions, safety etc. Since he was very much interested in productivity he was appointed as additional chief inspector for productivity. On hearing his promotion to the new position, his friend Mr..M. Mayilvaganam who was working as Joint Director of employment for a decade, moved the Government and achieved to create a post of Additional Director of Employment also promoted to that post. Similarly, Industrial department has created a post of Additional Director for frustrated and plateaued Senior Joint Director. Thus the plateau was overcome by promotion where the higher post is created by the motivation of one employee.

Every organisation whether it is a public or private, will have its own organisational structure, taking into consideration of the perspective psychological aspects of employees they can at least create some new positions/ designations which shall be more or less similar to the top positions. Of all the $6 \mathrm{Ms}$ human resource is the vital resource which has the power to regulate and control the rest of the Ms. Therefore, every organisation should take initiatives to retain the most valuable resource. Motivating the employees is essential in every organisation. This was done by Eswaramoorthy in the government institution Then why not many private organisations take initiatives to motivate the frustrated plateaued employees.

Eswaramoorthy is a person who took initiatives to restructure the organisational structure which is still prevailing which is not so easy task. The present generation should thank him for giving a remedy for plateaued employees which is beneficial for both employer and employee.

\section{Plateau due to familial situation}

Tackling the career plateau differs with gender. Many women due to their familial problems gets stagnated in the same organisation and also in the same position. Though they have knowledge and experience. A Women named S.Vasanthi completed her diploma in Electronic and Communication Engineering in Government women's polytechnic college, Palamaner in 1889. After completing her Diploma, she was placed in the same college as a lecturer. She worked as a lecturer

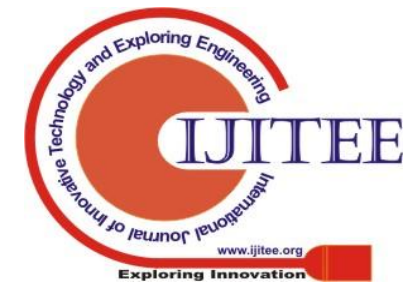


for two years. Then she has moved to Chennai and joined in a private organisation named Yoshinaka Electronics. In 1994 she has got an opportunity to get trained in Central Electronics Centre, IITMadras. In 1995 after completing her training she had joined in a project post in IIT Madras and worked till March 2000.

With the passion towards communication system she has joined in Midas communication technology as a Senior Technical Assistant in Apr 2000 and grown up step by step in the career with her hard work and finally when she left the organisation she holds the post of Senior Manager, Production. Though she had the scope of moving to higher position in similar organisation, she couldn't take it up due to her familial situation. Again, she opted to work as a consultant in IIT Madras from 2011 onwards. She continued to work in the same position only because of her familial situation. Till date she is working in the same organisation as a consultant.

Meantime she enhanced her studies also. She did BCA and MBA before leaving Midas Communications. Later did her M.Phil. in Management, also did her PhD in Management and LLB(Honours). Though she is well qualified she has sacrificed many good opportunities.

In this case we could observe that she has good educational qualification, abundant work experience in well-known organisations with good track record but still she could not go for career mobility only due to her familial conditions. In some exceptional cases even, the promotional strategies doesn't help to overcome the plateaued employees.

First case law explained here will discuss that there is a significant relationship between promotion and career plateau. The second case law gives a different view of the issue, personal situations playing major role in facing the career plateau.

\section{CAREER PLATEAU}

Career plateau is a point in an employee's career where he has reached to a peak point of career from which he cannot grow to higher level. There will not be any possibility. He will be stagnated at one position or will be assigned with routine or similar nature or works or responsibilities. There might be internal or external reasons for the career plateau of an employee.

External reasons for the career plateau can be reaching the highest position in the organisation where further higher positions are not existing or very few are existing. In case of smaller organisations, chances for turnover of senior management are very less hence the lower positioned employees will get stagnated in their positions. Promotion policies of the HRM will also play major role in the career plateau.

Internal reasons for career plateau can be the lack of motivation of employee or lack of interest in developing the skills or knowledge. Lack of confidence or over confidence in performance of the current position. Lack of self interest of the employee to reach higher steps in career ladder is also an important internal reason for career plateau.

\section{RESULT AND CONCLUSION}

From the above discussions it is observed that the employee's can come out of the career plateau by the planning of HR with proper definition of promotional policies and transfers.

Organisational effectiveness can be improved by recognising employee's skill and knowledge and thereby to retain them though the strategies of promotion and transfers. This is a kind of reward for motivating the frustrated plateaued employees and also one of the important methods which is beneficial for both employers and employees.

Promotion strategies should be defined in an organisation with at most care after careful assessment and evaluation of one's skills, performance and several other factors. A nonbiased and acceptable to all policies should be followed while defining the HR policies for employee promotion transfers that will help the employee to get motivated as well as to overcome the career plateau.

Thus, a well-planned promotional and transfer strategy of the organisation will be helpful in handling the career plateau.

\section{REFERENCES}

1) Daud, K. A. K. (2014). The Impact of Slow Career Growth on Organizational Commitment and Job Satisfaction: A Study of a „Closed Government Agency in Malaysia. School of Management, College of Business, RMIT University.

2) Dries, N, Pepermans, R \& De Kerpel, E. (2008). Exploring four generations' beliefs about career: Is "satisfied" the new "successful"?' Journal of Managerial Psychology,

3) Farnham D. Human resources management in context. 2010;(April).

4) Pergamit, M. R., \& Veum, J. R. (1999). What is a promotion? Industrial and Labor Relations Review, 52(4), 581-601.

5) Dr. S. Rabiyathul Basariya, and Dr. Ramyar Rzgar Ahmed, "A Study on Attrition: Turnover intentions of employees", Jan 2019. International Journal of Civil Engineering and Technology (IJCIET), Volume 10, Issue 9. 
6) https://www.hrzone.com/hr-glossary/what-is-a-career-plateau

7) h t p s : / / journals.s a g e p b.com/doi / abs/10.1177/1059601114558062?journalCode=gomb

8) https://www.slideshare.net/sm_nitrkl/internal-mobility-80333809

9) https://www.vskills.in/certification/blog/promotion/ https://www.vskills. in/certification/blog/promotion/

10) h t t p : / / w w w y o u a r t c lelibrary.com/hrm/ job-promotions-definition-types-and-other-details/35324 